\title{
Retraction: Luciferase-transfected colon adenocarcinoma cell line (DLD-1) for use in Orthotopic Xenotransplantation studies
}

\author{
Muhammad Rashid Siddique ${ }^{1}$, Steve Shynder ${ }^{1}$, Muhammad Aqeel Ashraf ${ }^{2 *}$, Ismail Yusoff ${ }^{3}$ and Abdul Wajid ${ }^{4}$
}

\section{Retraction}

This article is retracted.

The data in this article [1] was used without permission by the lead author Muhammad Rashid Siddique.

The lead author accepts full responsibility and would like to apologize to the owners of the data (Dr Steve Shnyder, University of Bradford, UK), as well as the co-authors of this article, the Editors and readers.

\footnotetext{
Author details

${ }^{1}$ Guy Hilton Research Centre, Keele University, Staffordshire, UK. ${ }^{2}$ Department of Chemistry, University of Malaya, 50603, Kuala Lumpur, Malaysia. ${ }^{3}$ Department of Geology, University of Malaya, 50603, Kuala Lumpur, Malaysia. ${ }^{4}$ Deprtment of Chemistry, The Islamia University of Bahawlapur, Bahawlapur 63100, Pakistan.
}

Received: 17 October 2012 Accepted: 18 October 2012

Published: 22 October 2012

\section{References}

1. Siddique MR, Shnyder S, Ashraf MA, Yusoff I, Wajid A: Luciferasetransfected colon adenocarcinoma cell line (DLD-1) for use in Orthotopic Xenotransplantation studies. Chem Central J 2012, 6:69.

* Correspondence: chemaqeel@gmail.com

²Department of Chemistry, University of Malaya, 50603, Kuala Lumpur, Malaysia
Publish with ChemistryCentral and every scientist can read your work free of charge

"Open access provides opportunities to our colleagues in other parts of the globe, by allowing anyone to view the content free of charge."

W. Jeffery Hurst, The Hershey Company.

- available free of charge to the entire scientific community

- peer reviewed and published immediately upon acceptance

- cited in PubMed and archived on PubMed Central

- yours - you keep the copyright

Submit your manuscript here:

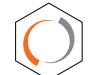

http://www.chemistrycentral.com/manuscript/ 